\title{
A Comparative Analysis of MAPK and Akt Phosphorylation in Prostate Cancer Tissues
}

\author{
Bo Wan1, Qing Zeng ${ }^{1^{*}}$, Yingmiao Liu ${ }^{2}$ \\ ${ }^{1}$ Department of Urology, Third Xiangya Hospital, Central South University, \\ Changsha, Hunan 410013, P.R. China; \\ ${ }^{2}$ Department of Medicine, Duke University Medical Center, Durham, NC \\ 27710, USA.
}

*Corresponding Author: Qing Zeng, Email: wanbo0118@sina.com.

\section{ABSTRACT}

Background: Prostate cancer is a common male urogenital system malignant tumor which is increasing worldwide. Molecular markers for early diagnosis and target therapy of it are not yet clinically available.

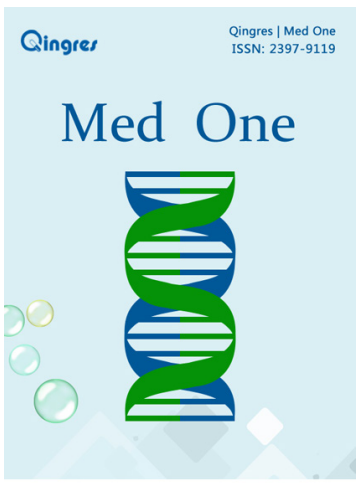

http://mo.qingres.com

\section{GOPEN ACCESS}

DOI: 10.20900/mo.20160002

Received: November 6, 2015

Accepted: January 17, 2016

Published: February 25, 2016

Copyright: $\odot 2016$ Cain et al. This is an open access article distributed under the terms of the Creative Commons Attribution License, which permits unrestricted use, distribution, and reproduction in any medium, provided the original author and source are credited.
Methods: A total of 71 prostate cancer and 10 benign prostatic hyperplasia tissues were collected for immunohistochemistry and Western blot assay of phosphorylated MAPK (Thr202) and Akt (Ser473) levels.

Results: Gleason grading resulted in classifying 15 prostate cancer tissues as well-differentiated, 25 as moderately-differentiated, and 31 as poorly-differentiated. Immunohistochemical staining showed that levels of phosphorylated Akt level were higher, and phosphorylated MAPK were lower, in prostate cancer tissues compared to benign prostatic hyperplasia tissues. Elevated p-Akt/Akt, and reduced p-MAPK/ MAPK ratios correlated with poor differentiation of prostate cancer.

Conclusion: In prostate cancer tissues, p-Akt levels were elevated and $\mathrm{p}-\mathrm{MAPK}$ protein levels were lowered. Low p-MAPK protein levels may be caused by higher $p$-Akt levels. p-Akt/p-MAPK ratio increases may provide a diagnostic marker for early prostate cancer diagnosis.

Key Words: Prostate cancer; Gleason grading; MAPK; Akt; Phosphorylation

\section{INTRODUCTION}


Prostate cancer is a common male urogenital system cancer. Prostate cancer ranks second, in terms of incidence and mortality, for malignant tumors in European and American men ${ }^{[1]}$. Prostate cancer incidence in China is increasing due to unhealthy lifestyles and aging ${ }^{[2]}$. Early diagnosis and active treatment strategies can greatly improve prostate cancer patient prognoses but the mortality rate is still high due its malignancy ${ }^{[3]}$. Current diagnostic methods for prostate cancer include serum PSA level measurement and histopathological staining. These methods do not provide either early, or accurate diagnoses ${ }^{[4]}$. An effective biomarker for early diagnosis and targeted treatment is urgently needed.

Protein kinase $B$, also known as Akt, and mitogen-activated protein kinase (MAPK) are, respectively, the key proteins in the PI3K/Akt signaling, and MAPK signaling, pathways ${ }^{[5,6]}$. A number of studies have reported that PI3K/ Akt signaling, and MAPK signaling, pathways closely associate with cell proliferation and invasion in a variety of malignant tumors ${ }^{[7,8]}$. Activation of the PI3K/Akt signaling pathway can lead to apoptosis protein BAD phosphorylation and other proteins to suppress cell apoptosis ${ }^{[5]}$. MAPK signaling pathway activation can promote excessive tumor cell proliferation leading to oncogenesis ${ }^{[6]}$. Phosphorylated Akt levels in human prostate cancer tissues have been measured by immunohistochemistry with controversial findings.

Waalkes et al. observed a significantly lower p-Akt expressions in prostate cancer tissues compared to normal prostate tissue $(p=0.028)^{[9]}$. $p$-Akt protein levels were found to be significantly higher in prostate cancer tissues than in benign prostatic hyperplasia or high-grade prostatic intraepithelial neoplasia tissues ${ }^{[10]}$. Ko et al. demonstrated that the p-Akt ratio in prostate cancer tissues was significantly lower than that in highgrade prostatic intraepithelial neoplasia tissues ${ }^{[11]}$. Che et al. reported that p38 MAPK levels significantly correlated with tumor progression and prostate cancer patient survival ${ }^{[12]}$. Phospho-MAPK levels in prostate cancer tissues has, to our knowledge, yet been investigated and reported on. Any relationship between Akt and MAPK phosphorylation in prostate cancer has not been addressed.

This study investigated MAPK and Akt phosphorylation in prostate cancer tissues and benign prostatic hyperplasia (BPH) using immunohistochemistry and Western blot.

\section{MATERIALS AND METHODS}

\subsection{Subject selection}

A total of 71 prostate cancer tissues were collected at our Department between January 2013 and December 2014. Prostate cancer patient mean age was $56.2 \pm 6.5(52-68)$. None received radiotherapy, chemotherapy, or immunotherapy before surgery. Benign prostatic hyperplasia (BPH) tissues were also collected from $10 \mathrm{BPH}$ patients during the same period. BPH patient mean age was $54.1 \pm 3.5(45-63)$. The tissues collected were kept in liquid nitrogen, or fixed by $10 \%$ formaldehyde for paraffin embedding. This study was approved by the ethics committee of The Third Xiangya Hospital. The signed informed consent form was obtained from all subjects.

\subsection{HE staining and Gleason grading}

Paraffin embedded tissues were sectioned at a thickness of $5 \mu \mathrm{m}$. Paraffin sections were baked at $60^{\circ} \mathrm{C}$ for $30 \mathrm{~min}$, and then rinsed in dimethyl benzene for $15 \mathrm{~min}$ to deparaffinize prior to hematoxylin and eosin (HE) staining. After removing the dimethyl benzene from gradient alcohol, the sections were twice washed with distilled water. Next, the sections were stained with hematoxylin for $15 \mathrm{~min}$ and twice washed with distilled water. After differentiation suing $1 \%$ hydrochloric acid alcohol for $30 \mathrm{~s}$, the sections were further washed in distilled water for $15 \mathrm{~min}$. The sections were then stained with $1 \%$ eosin for 3 min and rinsed in $70 \%$ alcohol. Finally, the sections were soaked in a xylene-alcohol mixture (1:1), for $5 \mathrm{~min}$, then soaked in xylene for $5 \mathrm{~min}$ and $15 \mathrm{~min}$. Slices were mounted and observed under a microscope. The Gleason grading system was used to classify tumor tissues as being: from well-differentiated (level 1 , score 1) to undifferentiated (level 5 , score 5 ). If tumor tissue differentiation was heterogeneous, a Gleason Score (GS) was obtained by primary and secondary structure scores. For single-structure tissue, the GS was doubled to obtain its final score ${ }^{[13]}$.

\subsection{Immunohistochemistry}

p-AKT and p-MAPK protein expression in tissues was detected by immunohistochemistry. Paraffinembedded sections were deparaffinized using xylene, gradient alcohol, and distilled water. The sections were incubated with $3 \% \mathrm{H}_{2} \mathrm{O}_{2}$ solution 
to block peroxidase activity for $10 \mathrm{~min}$ at room temperature (RT). After blocking with a $5 \%$ BSA solution at RT, the sections were incubated with a primary antibody (1:2000 dilution for Ser473 p-AKT and Thr183 p-MAPK) at $37^{\circ} \mathrm{C}$ for $2 \mathrm{hrs}$. After washing with $1 \times \mathrm{PBS}$, the sections were incubated with a biotin-conjugated secondary antibody $(1: 1000)$ at $37^{\circ} \mathrm{C}$ for $30 \mathrm{~min}$. The sections were then incubated with HRP-conjugated streptavidin at $37^{\circ} \mathrm{C}$ for $30 \mathrm{~min}$. After washing with $1 \times$ PBS, the sections were developed using DAB chromogenic agents for $10 \mathrm{~min}$. The reaction was then stopped, and the sections were washed with distilled water. After hematoxylin counterstaining, dehydration, hyalinization, and mounting, the sections were observed under a microscope. Five random fields were selected under a high-power field (400X) to calculate total cell count and positively-stained cell count $^{[14]}$.

\subsection{Western blot}

Total protein was extracted from cells using an RIPA buffer. The proteins were separated on a $15 \%$ SDS-PAGE gel and electrophoretically transferred to PVDF membranes. After being blocked using a TBST buffer containing $5 \%$ skim milk at $37^{\circ} \mathrm{C}$ for 1 $\mathrm{hr}$, the membranes were incubated with a primary antibody (anti-Akt, anti-Akt Ser473, anti-MAPK, and anti-p-MAPK were purchased from Cell Signaling Technology Inc., 1000 dilution) at $4^{\circ} \mathrm{C}$ overnight. After washing with a TBST buffer, the membranes were incubated in an HRP-conjugated IgG secondary antibody (1:1000) at RT for $1 \mathrm{hr}$. The membranes were then incubated with chromogenic substrates and exposed to X-ray films. Protein band optical densities were scanned and analyzed as previously described $^{[15]}$.

\subsection{Statistical analysis}

All statistical analyses were performed using SPSS 20.0 statistical software. Qualitative data was compared using the Kruskal-Wallis Test. Enumeration data were presented as either, rate or percentage, and compared using the chi-square test. Measurement data is presented as mean \pm standard error and compared by using either $t$ test or oneway ANOVA. A two-tailed $p<0.05$ was considered statistically significant.

\section{RESULTS}

\subsection{HE staining and Gleason grading}

The prostate tumor tissues were HE-stained (Fig. 1) for Gleason grading (Table 1). After grading 18 cases had a GS of 2-4 points. In these, mediumsized glandular tumor tissue was observed, but no, or only minor, infiltration phenomenon appeared in the tumor margin (Fig. 1b). Twenty-five cases were graded with a GS of 5-7 points. In these, dispersed dysplastic glands and obvious interstitial infiltration were observed (Fig. 1c). Thirty-one cases were graded with a GS of 8-10 points. In these, almost no adenoid structures, or acini fusion, were be found. Tumor cells had flake-like, funicular, or single-celled structures, and severe diffuse infiltration appeared (Fig. 1d).

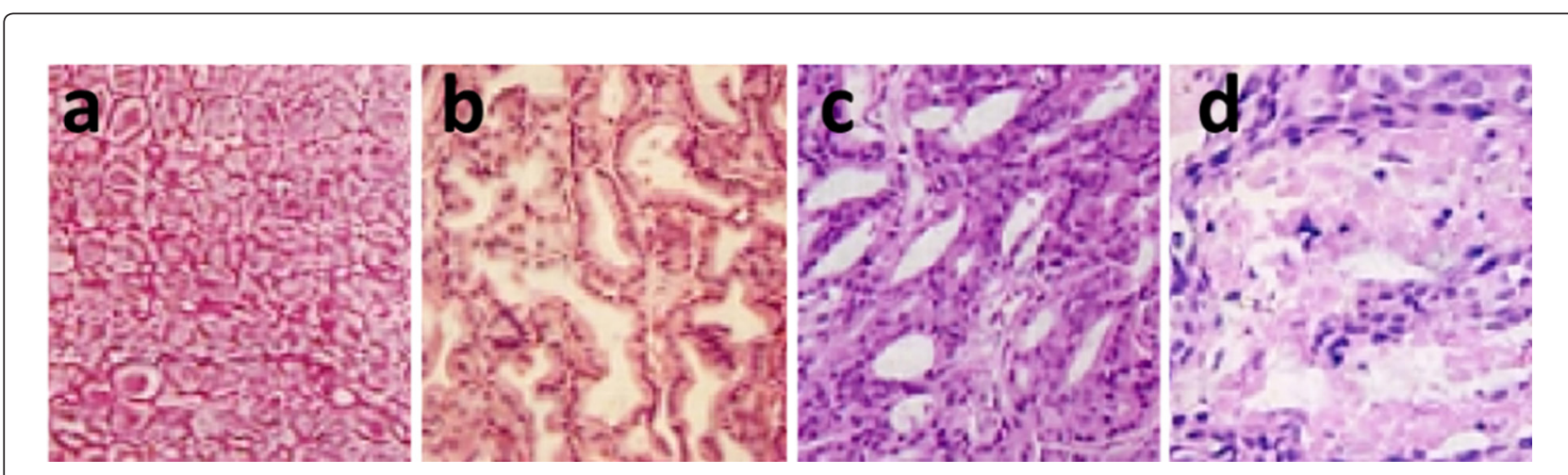

Fig. 1 HE staining of prostate cancer tissues $(100 \times)$ a, BPH tissue; b, prostate cancer tissue at 2-4 points; c, prostate cancer tissue at 5-7 points; $d$, prostate cancer tissue at 8-10 points. 
Table 1. Gleason grading of prostate cancer

\begin{tabular}{|c|c|c|c|c|c|c|c|c|c|}
\hline \multirow[b]{2}{*}{ Gleason score } & \multicolumn{3}{|c|}{ Well-differentiation } & \multicolumn{3}{|c|}{ Intermediate-differentiation } & \multicolumn{3}{|c|}{ Poorly-differentiation } \\
\hline & 2 & 3 & 4 & 5 & 6 & 7 & 8 & 9 & 10 \\
\hline Cases & 2 & 6 & 7 & 6 & 10 & 9 & 10 & 8 & 13 \\
\hline Total case No. & \multicolumn{3}{|c|}{15} & \multicolumn{3}{|c|}{25} & \multicolumn{3}{|c|}{31} \\
\hline
\end{tabular}

\subsection{Immunohistochemistry}

Immunohistochemical staining showed that phosphorylated Akt and MAPK proteins were usually in the cytoplasm (Fig. 2). P-Akt staining was positive in a part of prostate cancer tissues, and a part of $\mathrm{BPH}$ tissues. P-Akt staining intensity was stronger in prostate cancer tissues than that in BPH tissues, suggesting that $\mathrm{p}$-Akt overexpressed in prostate cancer. Positive p-MAPK staining was observed in only part of prostate cancer tissue and part of $\mathrm{BPH}$ tissue. p-MAPk staining intensity was weaker in prostate cancer tissues than that in BPH tissues. Proliferation correlated negatively with $\mathrm{p}$-Akt protein levels, but positively with p-MAPk levels.

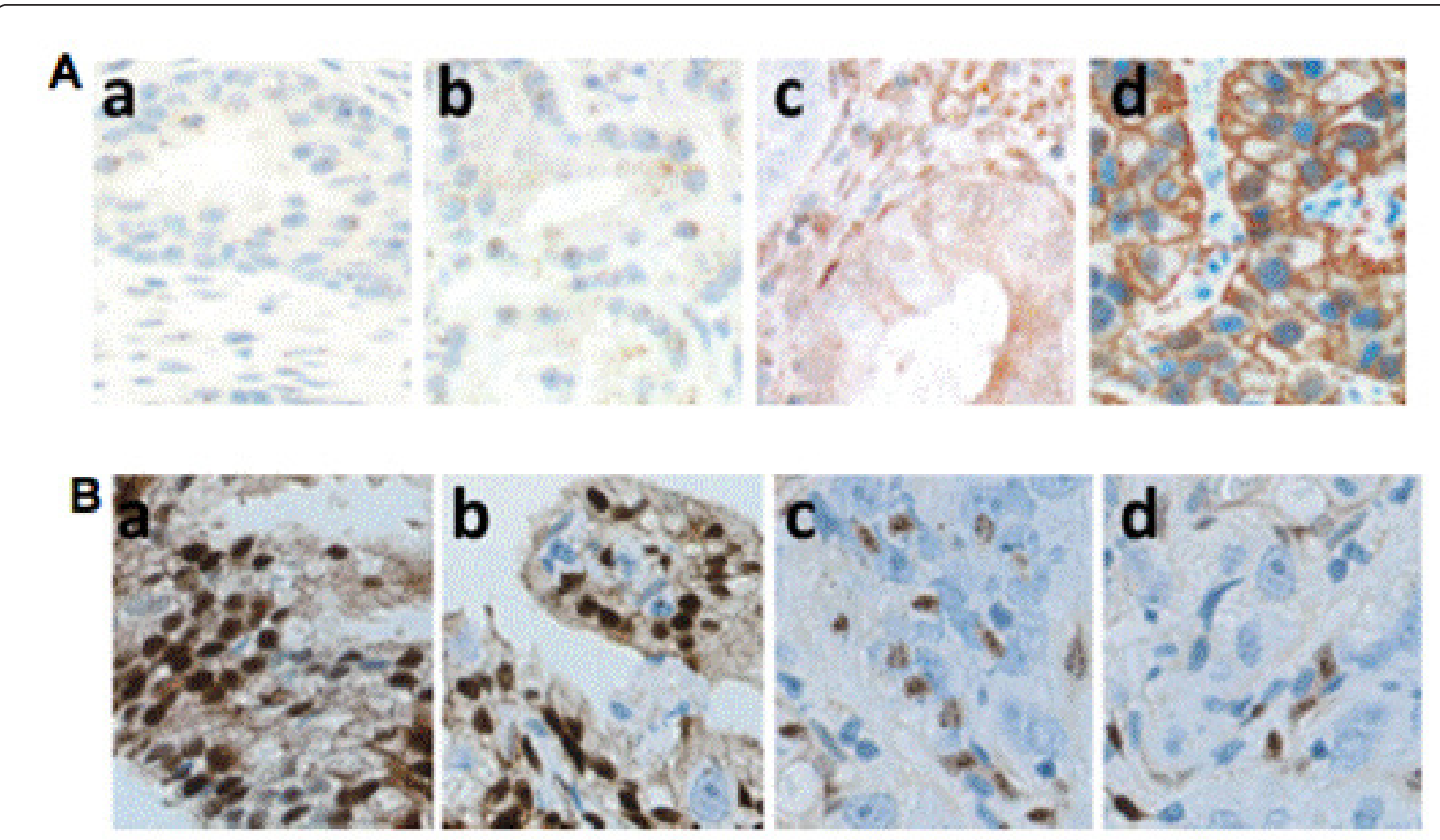

Fig. 2 Immunohistochemistry of p-Akt and p-MAPK. A) p-Akt immunohistochemistry (400x). B) p-MAPK immunohistochemistry (400x). a, BPH tissue; b, well-differentiated prostate cancer tissue; c, intermediate-differentiated prostate cancer tissue; d, poorly-differentiated prostate cancer tissue. 
3.3 The relationship between p-Akt and p-MAPK protein level in prostate cancer tissues

Total, and phosphorylated, Akt and MAPK protein levels in prostate cancer tissues were measured using Western blot (Fig. 3A). p-Akt ratios to total Akt and p-MAPK ratios to total MAPK protein levels were calculated (Fig. 3B). The p-Akt/total Akt ratio increased, whereas the $\mathrm{p}-\mathrm{MAPK} /$ total MAPK ratio decreased in prostate cancer with a poorer differentiation $(p<0.05)$.

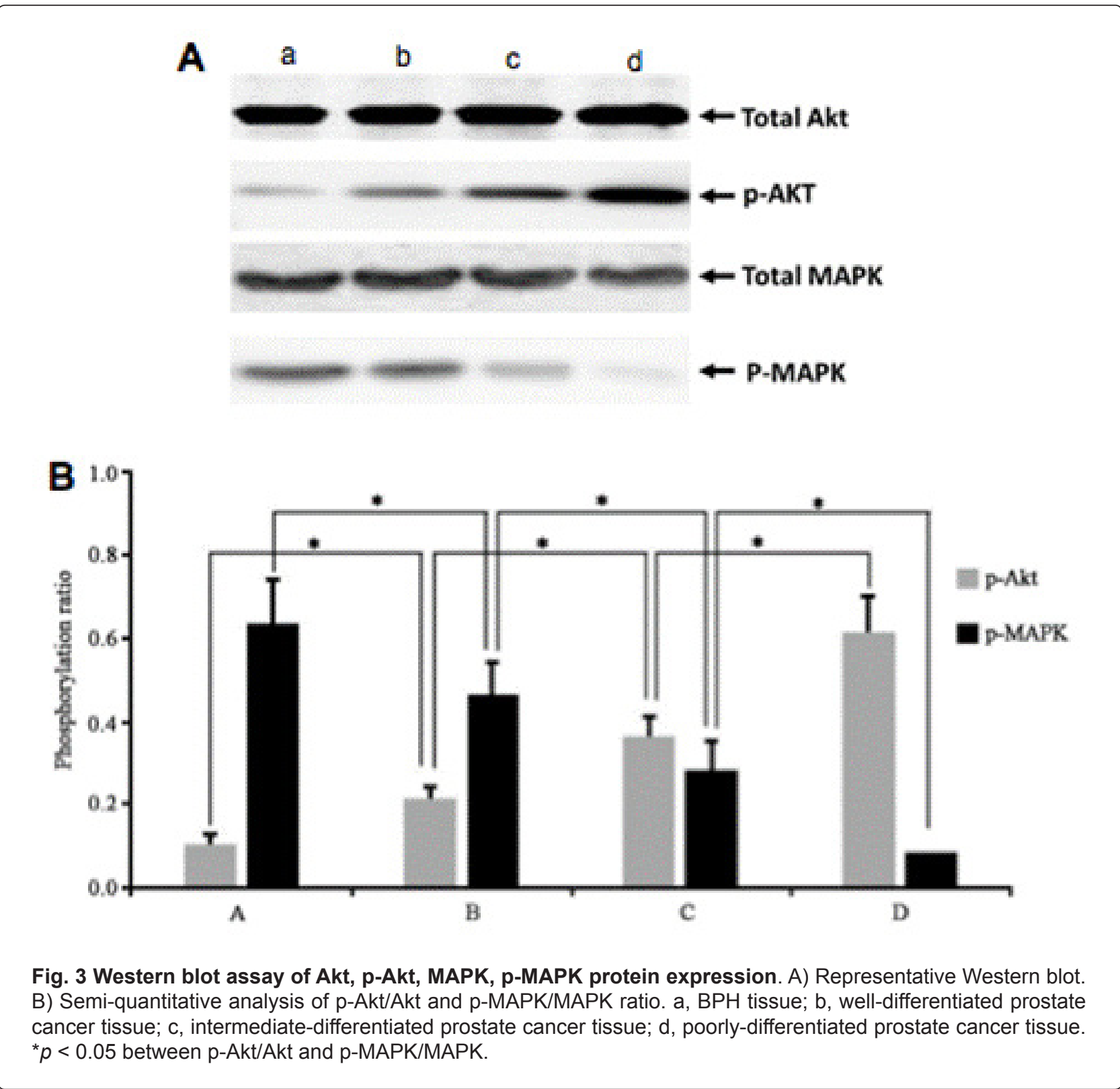




\section{DISCUSSION}

Previous studies have compared the tissues. This suggests that Akt and MAPK phosphorylation associates prostate cancer differentiation.

Akt is a serine / threonine-specific protein kinase that plays an important role in cell proliferation and division. Akt can promote phosphorylation of the proapoptosis protein BAD, leading to its dysfunction and inhibiting cell apoptosis ${ }^{[16]}$. Akt can reduce p27kip1 protein expression which shortens the cell cycle and promotes cell division ${ }^{[17]}$. Akt protein phosphorylation is necessary for Akt function. Akt phosphorylation is regulated by $\mathrm{PI} 3 \mathrm{~K}$ and $\mathrm{PTEN}$ protein activity. PI3K can promote Akt phosphorylation. PTEN may inhibit PI3K activity and reduce Akt phosphorylation levels [18]. A previous study found that the PTEN encoding gene is deleted, and/or mutated, in some prostate cancer tissues, resulting in PTEN expression loss ${ }^{[19}$, ${ }^{201}$. This might be one of the reasons that p-Akt levels were higher in prostate cancer tissues than in benign prostatic hyperplasia tissues. High p-Akt levels were correlate with poor differentiation in this study.

MAPK is also involved in regulating cell proliferation as the downstream effector of the RAS signaling pathway. Activated MAPK can enter the

\section{REFERENCES}

1. Center MM, Jemal A, Lortet-Tieulent J, Ward E, Ferlay J, Brawley O, Bray F. International variation in prostate cancer incidence and mortality rates. Eur Urol. 2012; 61(6): 10791092.

2. Stanford JL, Ostrander EA. Familial prostate cancer. Epidemiol Rev. 2001; 23(1): 19-23.

3. Bechis SK, Carroll PR, Cooperberg MR. Impact of age at diagnosis on prostate cancer treatment and survival. J Clin Oncol. 2011; 29: 235-241.

4. Epstein JI, Amin MB, Beltran H, Lotan $T L$, Mosquera JM, Reuter VE, Robinson BD, Troncoso P, Rubin MA. Proposed morphologic classification of prostate cancer with neuroendocrine differentiation. Am J Surg Pathol. 2014; 38: 756-767.

5. Risso G, Blaustein M, Pozzi B, Mammi P, Srebrow A. Akt/PKB: one kinase, many modifications. Biochem J. 2015; 468(2): 203-214

6. Kyriakis JM, Avruch J. Mammalian MAPK signal transduction pathways activated by stress and nucleus to trigger transcription factors, resulting in cell proliferation and differentiation ${ }^{[21]}$. MAPK is activated by phosphorylation ${ }^{[22]}$. RAF inhibitors have been found to activate MAPK by relieving inhibitory autophosphorylation ${ }^{[23]}$. A study also revealed that $p$-Akt can decrease Raf protein activity by phosphorylating Ser259 on the Raf protein. This reduces MAPK phosphorylation levels ${ }^{[24]}$. This may explain why our study found increased p-Akt levels, but decreased p-MAPK protein levels, in prostate cancer tissues compared to benign prostatic hyperplasia tissues.

In conclusion, this study indicates that p-Akt levels are elevated, but p-MAPK protein levels are lower in prostate cancer tissues and suggests that high p-Akt levels may be one of the causes of low p-MAPK protein levels. Our findings suggest that a high $\mathrm{p}-\mathrm{Akt} / \mathrm{p}-\mathrm{MAPK}$ ratio might be a diagnostic marker for early diagnosis of prostate cancer.

\section{CONFLICT OF INTERESTS}

The authors declare that they have no conflict of interests. inflammation: a 10-year update. Physiol Rev. 2012; 92(2): 689-737.

7. Nacerddine K, Beaudry JB, Ginjala V, Westerman B, Mattiroli F, Song JY, van der Poel H, Ponz OB, Pritchard C, CornelissenSteijger P, Zevenhoven J, Tanger E, Sixma TK, Ganesan S, van Lohuizen M. Akt-mediated phosphorylation of Bmi1 modulates its oncogenic potential, E3 ligase activity, and DNA damage repair activity in mouse prostate cancer. J Clin Invest. 2012; 122(5): 1920-1932.

8. Hour MJ, Tsai SC, Wu HC, Lin MW, Chung JG, Wu JB, Chiang JH, Tsuzuki M, Yang JS. Antitumor effects of the novel quinazolinone MJ33: inhibition of metastasis through the MAPK, AKT, NF-kappaB and AP-1 signaling pathways in DU145 human prostate cancer cells. Int J Oncol. 2012; 41(4): 1513-1519.

9. Waalkes S, Simon P, Hennenlotter J, Knapp J, Tezval H, Serth J, Stenzl A, Kuczyk MA, Merseburger AS. Altered expression of Akt signaling pathway parameters in prostate 
needle biopsies derived from benign, adjacent and cancerous tissue. Oncol Rep. 2010; 23(5): 1257-1260.

10. Dai B, Kong YY, Ye DW, Ma CG, Zhou X, Yao XD. Activation of the mammalian target of rapamycin signalling pathway in prostate cancer and its association with patient clinicopathological characteristics. BJU Int. 2009; 104: 1009-1016.

11. Ko YH, Miyake H, Behnsawy HM, Cheon J, Fujisawa M. Limited significance of activated Aktmammalian target of rapamycin signaling pathway in prostate cancer progression. Urol Int. 2014; 93(2): 146-151.

12. Che JP, Li W, Yan Y, Liu M, Wang GC, Li QY, Yang B, Yao XD, Zheng JH. Expression and clinical significance of the nin one binding protein and p38 MAPK in prostate carcinoma. Int J Clin Exp Pathol. 2013; 6(11): 2300-2311.

13. Epstein JI, Feng Z, Trock BJ, Pierorazio PM. Upgrading and downgrading of prostate cancer from biopsy to radical prostatectomy: incidence and predictive factors using the modified Gleason grading system and factoring in tertiary grades. Eur Urol. 2012; 61(5): 1019-1024.

14. Lotan TL, Gurel B, Sutcliffe S, Esopi D, Liu W, Xu J, Hicks JL, Park BH, Humphreys E, Partin AW, Han M, Netto GJ, Isaacs WB, De Marzo AM. PTEN protein loss by immunostaining: analytic validation and prognostic indicator for a high risk surgical cohort of prostate cancer patients. Clin Cancer Res. 2011; 17(20): 65636573.

15. Carver BS, Chapinski C, Wongvipat J, Hieronymus $\mathrm{H}$, Chen $\mathrm{Y}$, Chandarlapaty S, Arora VK, Le C, Koutcher J, Scher H, Scardino PT, Rosen N, Sawyers CL. Reciprocal feedback regulation of $\mathrm{PI} 3 \mathrm{~K}$ and androgen receptor signaling in PTEN-deficient prostate cancer. Cancer Cell. 2011; 19(5): 575-586.

16. Koh PO. Ferulic acid prevents the cerebral ischemic injury-induced decrease of Akt and Bad phosphorylation. Neurosci Lett. 2012; 507(2): 156-160.

17. Tan W, Gu Z, Shen B, Jiang J, Meng Y, Da Z, Liu H, Tao T, Cheng C. PTEN/Akt-p27(kip1) Signaling Promote the BM-MSCs Senescence and Apoptosis in SLE Patients. J Cell Biochem. 2015; 116(8): 1583-1594.

18. Ying J, Xu Q, Liu B, Zhang G, Chen L, Pan H. The expression of the PI3K/AKT/mTOR pathway in gastric cancer and its role in gastric cancer prognosis. Onco Targets Ther. 2015; 8: 24272433.

19. Mithal P, Allott E, Gerber L, Reid J, Welbourn W, Tikishvili E, Park J, Younus A, Sangale Z, Lanchbury JS, Stone S, Freedland SJ. PTEN loss in biopsy tissue predicts poor clinical outcomes in prostate cancer. Int J Urol. 2014; 21(12): 1209-1214.

20. Bar-Shira A, Matarasso N, Rosner S, Bercovich $D$, Matzkin H, Orr-Urtreger A. Mutation screening and association study of the candidate prostate cancer susceptibility genes MSR1, PTEN, and KLF6. Prostate. 2006; 66(10): 1052-1060.

21. Cargnello M, Roux PP. Activation and function of the MAPKs and their substrates, the MAPKactivated protein kinases. Microbiol Mol Biol Rev. 2011; 75(1): 50-83.

22. Dhillon AS, Hagan S, Rath O, Kolch W. MAP kinase signalling pathways in cancer. Oncogene. 2007; 26(22): 3279-3290.

23. Holderfield $M$, Merritt $H$, Chan J, Wallroth $M$, Tandeske L, Zhai H, Tellew J, Hardy S, HekmatNejad M, Stuart DD, McCormick F, Nagel TE. RAF inhibitors activate the MAPK pathway by relieving inhibitory autophosphorylation. Cancer Cell. 2013; 23(5): 594-602.

24. Aksamitiene E, Kiyatkin A, Kholodenko BN. Cross-talk between mitogenic Ras/MAPK and survival PI3K/Akt pathways: a fine balance. Biochem Soc Trans. 2012; 40(1): 139-146. 